\title{
FORMATION OF THE TOURIST AND RECREATIONAL FOREST POTENTIAL: METHODOLOGICAL AND STRATEGIC GUIDELINES FOR SYSTEM ASSESSMENT
}

Zhuravka F.,

Doctor of Economics, Professor,

Department of International Economic Relations, Sumy State University,

57 Petropavlivska Str., Sumy, 4000, Ukraine,

E-mail:f.zhuravka@uabs.sumdu.edu.ua

ORCID: https://orcid.org/0000-0001-8368-5743

Yarova I.

Ph.D. (Economic Sciences), Associate Professor,

Department of International Economic Relations,

Sumy State University,

57 Petropavlivska Str., Sumy, 4000, Ukraine,

E-mail:i.yarova@uabs.sumdu.edu.ua,

ORCID: https://orcid.org/0000-0001-9840-131X

Halynska Yu.,

Doctor of Economics, Associate Professor,

Department of International Economic Relations,

Sumy State University,

57 Petropavlivska Str., Sumy, 4000, Ukraine,

E-mail:y.halynska@management.sumdu.edu.ua

ORCID: https://orcid.org/0000-0002-8413-8968

Khomutenko L.,

Ph.D. (Economic Sciences), Associate Professor,

Department of International Economic Relations,

Sumy State University,

57 Petropavlivska Str., Sumy, 4000, Ukraine,

E-mail:l.khomutenko@uabs.sumdu.edu.ua,

ORCID:https://orcid.org/0000-0002-9443-4330

Domashenko M.,

Ph.D. (Economic Sciences), Associate Professor,

Department of International Economic Relations,

Sumy State University,

57 Petropavlivska Str., Sumy, 4000, Ukraine,

E-mail: m.domashenko@macro.sumdu.edu.ua

ORCID: https://orcid.org/0000-0002-6987-8992

The current state of spatial and territorial development of recreational nature management in Ukraine is characterized by the fact that the country has significant natural resource potential, unique recreational resources, as well as a valuable natural reserve fund. This proves that the possibility for further development and forestland use for recreational purposes, and the formation of spatial-territorial recreational systems with the involvement of forestlands can be widely developed. At the same time, this is a prerequisite for the active development of market relations in the field of recreational and tourist management, since the diversity and uniqueness of forest resource potential creates the opportunity to gain competitive advantages in using separate recreational resources that will provide high demand and prices for them. From these perspectives, the purpose of the paper is to deepen economic assessment of recreational forest resource potential for ensuring the formation of territorial forest resource assets (natural capital) in the context of strategic guidelines for sustainable forestry spatial development.

The main principles of formation of the territorial and recreational forest resource potential (capital) have been considered in this paper. Also, it should be taken into account that, at present, the methods of economic (cost) estimation of certain types of natural resources, which are involved in economic activity and recreational activities, are well-developed and widely used. Therefore it should be noted that the problem of an integrated system 
assessment of territorial forest resource capital is relevant for the recreational use of forest lands, since it is necessary to evaluate, as far as possible, and more fully, all of its components, for the effective decision-making in the management mechanism. The scheme of the system assessment of the territorial and recreational forest potential (TRFP) has been developed and represented.

The main objectives of ecosystem management of forest areas in the context of providing balanced recreational forestland management have been determined. It was concluded that comprehensive and system assessment of recreational forest resource capital based on the application of the natural capital methodology and the concept of total economic value (value) should become an effective lever in the market-oriented mechanism of forest management in the spatial and territorial format. The article identifies theoretical and conceptual guidelines for system assessment of territorial forest capital in the context of spatial development strategies.

Keywords: territorial and recreational forest resource capital, economic assessment, tourist forest resource potential, spatial development, strategy.

DOI: $10.21272 / 1817-9215.2021 .3-7$

\section{PROBLEM SETTING}

The modern world paradigm of improving the efficiency of local resources, including natural ones, is based on the territorial capital concept. Territorial capital formation is associated with ensuring and competitiveness of sustainable regional development and fuller realization of endogenous potential of spatial and territorial economic systems. This is manifested, in particular: in increasing financial returns from the local resources use, increasing added value, harmonizing economic interests of territorial communities and business and entrepreneurial structures [1-4].

The paradigmatic tendencies for sustainable regional development in the context of the formation of territorial natural resource capital are relevant for the spatial development of the forestry. Strategic guidelines for spatial and territorial forest management in the context of decentralization require a system assessment of forest (forest resource) potential and territorial recreational forest capital $[5,6]$.

\section{ANALYSIS OF THE RECENT RESEARCH AND PUBLICATIONS}

The methodology of forest management and formation of forest resource capital in the context of sustainable development is covered, in particular, in the studies of Antonenko, I.Ya., Drebot, O.I., Koval, Ya.V., Lytsur, I.M., Mishenin, Ye.V., Furdychko, O.I., Shershun, M.H., Shkuratov, O.I., etc. [7-11].

A key component of national sustainable development is taking into account the global role of forests. Large-scale processes of deforestation and significant degradation of forest ecosystems cause negative phenomena not only at the national but also at the global level, including: disruption of natural cycles and global climate change, declining biodiversity, growing socio-ecological and economic problems of rural areas, etc.

Awareness of the important role of forests in the well-being of the world community has led to the transition of humanity from national forests to global forestry. The main directions of formation and development of global forestry, based on existing scientific publications and documents of forest environmental organizations, can be summarized as follows: increasing the forest area of different countries and the planet as a whole; preservation and protection of forests; forest management in accordance with the principles of sustainable development; mixed agricultural and forest land use; increasing the role of recreational forest use; increasing the area of "carbon" forests, etc.[1-3].

In particular, the issue on the development of scientific approaches to the formation of financial and economic mechanism of project management of territorial economic complexes on the basis of regional use of existing natural resources has been fundamentally studied by scientists of the Institute of Economics of Nature Management and Sustainable Development of the National Academy of Sciences of Ukraine [7-11]. However, a research should be focused on issues related to the comprehensive and system assessment of territorial recreational forest capital in the context of sustainable forestry. 


\section{AIM OF THE PAPER}

The aim of the research is to deepen economic assessment of recreational forest resource potential for ensuring the formation of territorial forest resource assets (natural capital) in the context of strategic guidelines for sustainable forestry spatial development.

STATEMENT OF THE MAIN RESEARCH MATERIAL

For recreational use, it is necessary to designate forest areas with a sufficiently high recreational potential - resistant to recreational loads and convenient for use. The recreational potential of a forest landscape can be considered as a measure to perform recreational functions, due to its natural properties and the results of human activity.

Recreational forest potential should be aimed at specific forest management, use regime, protection and preservation for getting a certain income from recreants, which after a certain period of time will become greater in comparison with the traditional economic forest use (cutting), since it will not be "one-time", but constant. Therefore, recreational forest potential (capital) should be related to the separate category in the forest fund.

A capital is an asset with the potential to generate future benefits. Recreational forest capital includes objects of natural origin that provide long-term economic productivity in the recreational and tourist spheres as well as socio-ecological and economic well-being of the society, economic entities and individuals. Forest capital is measured by means of its inventories and flows expressed in physical units (the value of stocks and flows of natural capital can be expressed in monetary units because of the product of the price per unit of the resource and its quantity, but such a procedure is often problematic due to imperfections in resource markets and, consequently, distorted prices) [5]. From these perspectives, until now, the economic aspects of recreational forest use are quite controversial from the standpoint of constant significant income. That is why, possible income sources can be considered as follows: a forest area lease for various types of recreational activities; payment for forest monitoring in leased areas; provision of various services to vacationers (vehicles - horses, bicycles, etc., leisure facilities - tents, parking lots, organizing picnics, etc.); "ecological tourism" development - organized visits by tourists, including foreign tourists, to beautiful undisturbed landscapes; trading activities (popular science literature on the nature of recreational facilities, flora and fauna, maps and plans, souvenirs, etc.); incidental forest use (mushrooms, berries, medicinal plants, etc.).

Territorial recreational forest resource capital can be considered as an endogenous factor that can determine the development trajectories of the territorial economic and forest resource complex [7]. The active form of the components of recreational forest resource potential (capital) involves their integration into a certain economic, financial, social, institutional space of forestry on the basis of appropriate management mechanisms [7,12,13]. Thus, it requires a comprehensive and system assessment of the territorial recreational forest resource potential (capital) in the context of the transformation of forest management in the context of decentralization.

It is worth noting that currently well-developed and widely used rental and cost methods of economic (cost) valuation of certain types of natural resources, which are involved in economic circulation within the spatial organization of nature management and have welldeveloped regional markets. So, not all natural and ecological resources have market prices (ecosystem services, public forest ecological goods and services), although they are used in the field of integrated nature management and in spatio-temporal dimension affect the socioecological well-being of society, individuals, aesthetics and environment [5].

And each component (function, resource of recreational forest potential) does not exist in itself, separately from other components of the natural environment (land, water, wetlands, etc.), and their use is reflected to the state (assessment) of the whole set of resources (including those that do not have market prices). Thus, the value of forest resource potential as a whole changes. It is necessary to assess all components of forest resource capital 
(potential) in the territorial, spatial and temporal dimension. For example, conservation and nature restoration components of forest potential are the key parameters for recreational forest use.

The problem of comprehensive and system assessment of recreational forest resource potential (capital) is relevant for spatial and territorial forest management, as it is necessary to more fully assess all its components for making appropriate decisions in the mechanism of ecosystem forest management.

The system assessment of spatial and territorial forestry involves economic, social and environmental assessments and their various combinations. Such aggregate estimates simultaneously determine the links of the regional natural economic system [14]: socioeconomic - direct links in the field of social production; economic and environmental - the impact of natural (forest) resources on the conditions of social production; ecological and economic - nature management and other types of impact of economic activity on the environment; ecological and social - the direct impact of the population on the environment. At the same time, direct links are ecological-economic and ecological-social, which reflect the impact on the environment. Inverse relationships (economic-ecological and socioecological) characterize the impact of changes in environmental parameters on social production and population. The implementation of certain directions for balanced spatial and territorial recreational forest management in the system (mechanism) of ecosystem forest management (forest resource potential) requires its system assessment. The procedure of such assessment is presented in figure 1.

Evaluation at any stage begins with the formation of the most rational forestry strategy. The formation of the strategy of spatial and territorial forestry is carried out by a decisionmaker (DM) with certain targets, provided with a set of value criteria and institutional legal regulations to represent the governmental (regional, territorial communities) socio-economic and environmental-economic interests. At different stages of the assessment, the role of DM in the formation and selection of scenarios for the transformation of forest management space may belong to different hierarchies of individuals or groups (within nature management institutions, local communities).

The scenario specifies possible options for reproduction processes using forestenvironmental innovative technologies. It is necessary to determine the extent of violations for forest ecosystems, the amount of pollution, as well as patterns of distribution and dynamics of forestry. It is important to emphasize that the level of anthropogenic impact is the main criterion of acceptability or rejection of this variant of the scenario for sustainable recreational forest management.

The assimilation potential of the recreational area may be an ecological constraint for the forest management space transformation. It should also be noted that the economic aspect is the most important, integrated component of the entire forest management assessment system. The results of the economic assessment largely determine the further actions of the decision-maker regarding the strategy, for example, the capitalization of forest resources. This role of economic evaluation determines the justification of the method of its implementation and the choice of appropriate criteria for socio-ecological and economic indicators.

Improving the organizational and economic mechanism for managing the sustainable development for forestry space through the use of economic (cost) methods, involves the widespread use of estimates for natural capital in its various interpretations. Regarding forest resource capital we include objectified components of natural origin, which provide longterm economic productivity in various areas of forestry and ensure the socio-ecological and economic well-being of society, businesses and individuals.

By analogy with financial capital, natural capital is measured using indicators of its stocks and flows, usually expressed in physical units (the values of stocks and flows of natural 
capital can be expressed in monetary units through the product of the unit price and its quantity, but such a procedure is often problematic due to the imperfection of resource markets and, as a consequence, distorted prices).

In order to conduct the market evaluation of natural capital, a set of "natural assets" should be taken into consideration; this set offers the society various resources (natural, mineral, energy, water, biological, soils, etc.) and ecosystem services, the use of which leads to obtaining economic and social benefits of production and society as a whole.

Indicators for estimating the state of natural capital are divided into three groups: indicators of economic evaluation of natural resources, indicators of economic evaluation of ecosystem services, and indicators for assessing the economic damage caused by anthropogenic changes in the environment (ecosystems).

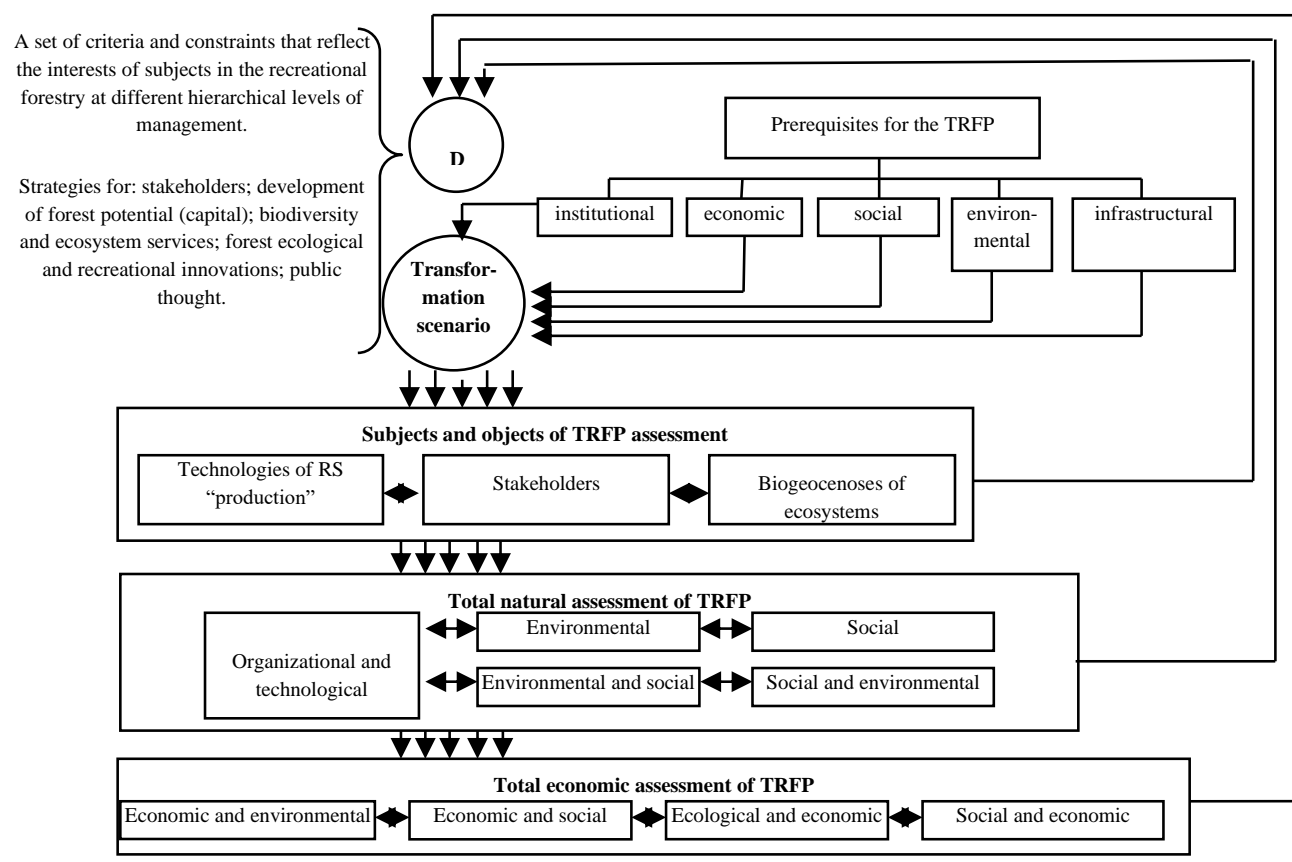

Figure 1 - Scheme of system assessment for Territorial and Recreational Forest Potential (TRFP): DM - decision maker; $R S$ - recreational services; $E S$-ecosystem services

An analysis of existing methods for the economic assessment of natural resources suggests that the concept of total economic value (TEV) corresponds to the most complete task of the integrated and systematic assessment of recreational forestry, according to which various benefits are assessed both with and without the use of resources and services in the environment [5].

In order to conduct the market evaluation of natural capital, a set of "natural assets" should be taken into consideration; this set offers the society various resources (natural, mineral, energy, water, biological, soils, etc.) and ecosystem services, the use of which leads to obtaining economic and social benefits of production and society as a whole.

Indicators for estimating the state of natural capital are divided into three groups: indicators of economic evaluation of natural resources, indicators of economic evaluation of ecosystem services, and indicators for assessing the economic damage caused by anthropogenic changes in the environment (ecosystems).

An analysis of existing methods for the economic assessment of natural resources suggests that the concept of total economic value (TEV) corresponds to the most complete 
task of the integrated and systematic assessment of recreational forestry, according to which various benefits are assessed both with and without the use of resources and services in the environment. Total economic value (TEV) of the natural capital of recreational forestry is calculated as follows:

$$
\begin{gathered}
T E V=\text { Direct and indirect } u \text { se value }+ \text { Non-use value (option value + } \\
+ \text { existence value + request value }),
\end{gathered}
$$

Direct use value is measured by the income derived from the use of natural resources and ecosystem services.

Indirect use value is measured through additional revenues derived from the use of elements of the environment (for example, from providing recreational services, increased ecological and aesthetic comfort, etc.).

Option value is related to the possibility of deriving direct or indirect benefits from the future use of ecosystem services and recreational forest resources. It is measured through the willingness to pay for the conservation of elements of the environment with a view to their future use.

Existence value is related to satisfaction with the existence of a clean, diverse and productive environment of forests.

Request value is related to the desire to endure that our descendants will have the same opportunities in the sense of ecosystem services of forestlands.

The peculiarity of recreational forest resource capital is composition of a significant number of ecosystem goods (services, functions), which do not directly and explicitly participate in economic turnover and do not have a monetary value. The importance of this approach to an assessing not only the resource components, but also ecosystem services of forest biogeocenoses, which are not measured directly in monetary terms in the system of market relations (transactions) and have no instrumental value in the system of forest management transformation.

The total damage from the degradation of forest biogeocoenoses in the system of recreational land use consists of partial damage in accordance with the components of natural-territorial complexes and landscapes (forest, water, agro-forest biogeocoenoses, etc.). The ecological and economic assessment of the damage caused by the violation of biogeocoenosis in the system of recreational forestry management $\left(Y_{e-e}^{s}\right)$ can be determined by the following formula:

$$
Y_{e-e}^{S}=\sum_{t=1}^{T} \sum_{i}^{n} Y_{i}^{t} \frac{Z_{i}^{t}}{(1+E)^{t}}
$$

where $\boldsymbol{Y}_{\bar{i}}^{t}$ - the natural loss from the decline in productivity, the deterioration of the functional state and the reduction of the volume of ecosystem services and the element of forest biogeocoenosis, which is used in the $t$ - period of time;

$Z_{\bar{i}}^{t}-$ the economic value of the $i$ element of forest biogeocoenosis in the

$t$ - period of time;

$E_{-}$"time factor" coefficient;

$\mathrm{t}=1,2, \ldots, \mathrm{T}-$ period of time from the beginning of degradation of biogeocoenosis to its end and recovery. 
While conducting an environmental and economic assessment, it is also necessary to take into account the resistance of forest-based recreational systems (assimilation potential), and their ability for self-purification and self - healing. Ecological and social assessment is characterized by qualitative indicators, because it is very difficult (quantitatively) to estimate, for example, a deterioration of the comfort of rest or decrease of the aesthetic value of the agro-forest landscape [15]. In this case, the environmental and social assessment of the damage $Y_{c-e}^{s}$ can be defined as follows:

$$
Y_{e-c}^{S}=\sum_{i=1}^{n} m_{i}\left(C_{1 i}^{\prime}-C_{2 i}\right)
$$

where $m_{i}$ - is the element of the forest biogeocoenosis, the type of ecosystem or landscape;

$C_{1 i}, C_{2 i}$ - respectively, the social or ecological (socio-ecological) value of the $i$-th element before and after anthropogenic change.

So, there is a methodological position according to which only those elements of biogeocoenosis - ecosystems that are widespread or renewable - should be subject to environmental and economic assessment. Those components of ecosystems that are unique (relicts, endemics, etc.) or intended to preserve the gene fund, and those which are not subject to environmental and economic assessment, simply need to be preserved within the protected areas [15]. However, it is necessary to determine the cost of their conservation within the natural-economic systems (complexes). In the forest management mechanism, it is important to formulate incentive systems for the preservation of unique, rare ecosystem entities in the spatial dimension.

Thus, more attention should be paid to the development scenario of territorial recreational forest potential from the perspectives of applying methods of heuristic forecasting (expert estimation method, the method of collective generation of ideas, etc.). After determining the scenario of recreational forest potential development within protected areas, a hierarchy of problems and the tree of different goals are established. In relation to this scenario, the subsystems of the simulation model are developed, that is, a particular methodological model is formed for each subsystem. This is a general evaluation scheme. It depends on the peculiarities of recreational forestland management. Proceeding from this, the criteria and methods for systematic evaluation of recreational forest potential are selected.

The main dominant strategies in the field of territorial recreational forest management can be considered as follows: the strategy of ignoring the need for balanced recreational nature management; the strategy of neutralization and mitigation of the negative impact on nature-recreational objects; a strategy for supporting forest ecosystems and preventing their degradation; the strategy of compensation for damage to natural ecosystems and their recreational services; rational use of ecosystem services strategy; creation of prerequisites for new capital - intensive forest products and ecosystem services in the context of territorial and recreational forest capital [7].

Thus, comprehensive and system assessment of territorial and recreational forest potential based on the application of the natural capital methodology and the concept of total economic value should be an effective lever in the market-oriented mechanism of forest management in the spatial and territorial format.

\section{CONCLUSIONS}

The formation of territorial recreational forest resource capital requires a comprehensive and system assessment of forest resource potential, in particular, based on the application of the concept of total economic value (cost). 
Ecodestructive use of recreational forest resource potential can cause environmental and economic losses that do not meet the principles of sustainable spatial development of forestry and require appropriate assessment. Further research should focus on the financing of forest resources and the formation of integration links between local communities and business structures in the financial field.

\begin{abstract}
АНОТАЦІЯ
Журавка Ф.О., Ярова І.С., Галинська Ю.В., Хомутенко Л.І., Домашенко М.Д., Формування туристичнорекреаційного лісоресурсного потенціалу: методологічні та стратегічні оріснтири системної оцінки

Сучасна світова парадигма підвищення ефективності використання місцевих ресурсів, у тому числі природних, трунтується на конщепті територіального капіталу. Формування територіального капіталу пов'язується із забезпеченням та конкурентоспроможністю сталого регіонального розвитку та більш повною реалізацією ендогенного потенціалу просторово-територіальних економічних систем $і$ це має прояв, зокрема: у підвищенні фінансової віддачі від використання місцевих ресурсів, збільшення обсягів доданої вартості, гармонізації економічних інтересів територіальних громад $і$ бізнес-підприємницьких структур.

Окреслені парадигмальні тенденції сталого регіонального розвитку у контексті формування територіального природно-ресурсного капіталу актуальні для просторового розвитку лісового комплексу, лісогосподарювання. Стратегічні орієнтири просторово-територіального лісогосподарювання в умовах децентралізації потребують системної оцінки лісового (лісоресурсного) потенціалу та територіального рекреаційного лісоресурсного капіталу. Варто констатувати, шчо проблема комплексної та системної оцінки лісоресурсного потенціалу (капіталу) актуальна для просторово-територіального лісогосподарювання, оскільки необхідно по можливості більш повно оцінювати всі його складові для формування обтрунтованих рішень в механізмі екосистемного управління лісами.

Мета статті полягає у поглибленні економічної очінки лісоресурсного потениіалу (зокрема, рекреаційного) для забезпечення формування територіальних лісоресурсних активів (природного капіталу) у контексті стратегічних орієнтирів сталого просторового розвитку лісогосподарювання.

Реалізація тих чи інших напрямів збалансованого просторово-територіального лісогосподарювання 6 системі екосистемного управління лісоресурсним потенціалом потребує його системної оиінки. У даній роботі нами сформовано загальну схему системної оцінки територіального рекреаційного лісоресурсного потенціалу. У результаті дослідження також встановлено, щзо комплексна та системна оцінки вартості рекреачійного лісоресурсного потениіалу найбільи повно реалізується в рамках концепиії загальної економічної иінності (вартості). Саме формування територіального рекреаційного лісоресурсного капіталу потребує комплексної та системної оцінки лісоресурсного потенціалу, зокрема, на основі застосування концепиіі загальної економічної цінності (вартості). Екодеструктивне використання лісоресурсного потениіалу може спричиняти еколого-економічні збитки, які не відповідають приниипам сталого просторового розвитку лісогосподарювання $i$ потребують відповідної оцінки. Подальші дослідження дочільно спрямувати на фінансизачію лісоресурсного потениіалу та формування інтеграџійних зв'язків між територіальним громадами та бізнес-підприємницькими структурами у фінансовій площині.
\end{abstract}

Ключові слова: територіальний рекреаційний лісоресурсний капітал, економічна очінка, лісоресурсний потенціал, просторовий розвиток, стратегія.

\title{
REFERENCES
}

1. Forestry in Ukraine at the Crossroads. Problems and Perspectives for a Sustainable Development. (2001). Ed. by Hans-Friederich Essmann and Davide Pettenella. Moscow: Publishing House «Afisha».

2.FAO. Multifunctional Character of Agriculture and Land. Twenty second FAO Regional conference for Europe. URL: http://www.fao.org/docrep/meeting/X7073e.htm

3. European Commission (EC). Territorial state and perspectives of the European Union. Scoping Document and Summary of Political Messages 2019. URL: http://www.ccre.org/docs/territorial_state and_perspectives.pdf.

4. Konvitz J. W. (2010). Changing economies: The territorial dimension. Informationen zur Raumentwicklung, $11,657-663$

5. Mishenin, Ye., \& Yarova, I. (2020). Recreational and Tourist Use of Forestlands: Management Benchmarks for the System Evaluation in the Territorial and Spatial Format// Management. Tourism. Culture. Studies and Reflections on Tourism Management. Monograph. Edited by Lukasz Burkiewicz, Agnieszka Knap-Stefaniuk.Krakow: Ignatianum UniversityPress. 349 p. (33-47). URL: https://essuir.sumdu.edu.ua/handle/123456789/82506

6. Khvesyk, M.A. (2016). Finansovo-ekonomichny`j mexanizm upravlinnya tery`torial`ny`my` pry`rodnogospodars ky`my` kompleksamy` [Financial and economic mechanism of management of territorial natural and economic complexes]: monograph. Kyiv: IEPSR NAS, 528 p. [in Ukrainian].

7. Mishenin, Ye. V., Yarova, I.Ye., \& Mishenina, N.V. (2016). Sy`stemna ocinka rekreacijnogo zemlegospodaryuvannya u mexanizmi ekosy`stemnogo upravlinnya pry`rodooxoronny`my` tery`toriyamy` [System 
assessment of recreational land management in the mechanism of ecosystem management of protected area]. Balanced nature management, 3, 126-132. [in Ukrainian].

8. Antonenko, I. Ya. (2008). Ekologo-ekonomichni priory`tety` modernizaciyi liso- resursnogo kompleksu Ukrayiny`: makroekonomichni vazheli [Ecological and economic priorities of modernization of the forest-resource complex of Ukraine: macroeconomic levers] / Ed. by Prof. B.M. Danylyshyn. - Kyiv: KUTEP-Inform, 359 p.

9.Drebot, O.I., Shershun, M.H., \& Shkuratov, O.I. (2014). Zbalansovany`j rozvy`tok lisovogo sektoru ekonomiky` v konteksti yevropejs`koyi integraciyi Ukrayiny` [Balanced development of the forest sector of the economy in the context of European integration of Ukraine]: monograph. Ed. by Prof. O.I. Furdychko. - Kyiv: Agrarian science, 348 p. [in Ukrainian].

10. Lytsur, I.M. (2010). Ekologo-eoknomichni problemy` prostorovoyi organizaciyi lisovogo kompleksu Ukrayiny` [Ecological and economic problems of spatial organization of the forest complex of Ukraine] / Ed. by Professor, Academician of the National Academy of Sciences of Ukraine B.M. Danylyshyn.- Kyiv: RVPS of Ukraine of the National Academy of Sciences of Ukraine, 317 p. [in Ukrainian].

11. Koval, Ya.V., \& Antonenko, I.Ya. (2004). Ekonomichna (groshova) ocinka pry`rodny`x resursiv lisovogo fondu Ukrayiny`: teoriya, metodologiya, metody`ka [Economic (monetary) assessment of natural resources of the forest fund of Ukraine: theory, methodology and methodics]. - Kyiv: RVPS of Ukraine of the National Academy of Sciences of Ukraine, 2004.-163 p. [in Ukrainian].

12. Mishenin, Ye.V. \& Kovaleva, O.M. (2016). Kaiptal pidpry`yemstva: formuvannya ta vy`kory`stannya [Enterprise capital: formation and use]. - Sumy: PIB "Sognu", 388 p.

13. Mishenin, Ye. V., Yarova, I. Ye. (2019). Methodology for defining sustainable spatial forestry. Economic Innovations. Vol. 21. №3(72). pp.71-78 DOI: https://doi.org/10.31520/ei.2019.21.3(72).71-78

14. Blauberg, N.V. (1973). Formation and Essence of the System Approach, Moscow: Nauka.

15. Pakhomov, V.P. (1989). Assessment of Mineral Resources in Areas of New Economic Development (Economic, Ecological and Social Aspects), Moscow: Nauka. 